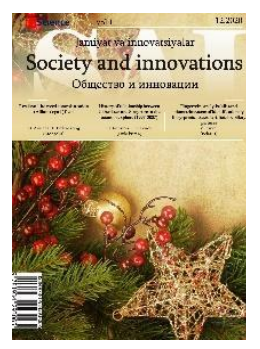

\title{
Prospects for further development of the National parliament in new Uzbekistan
}

\section{Akhtam TURSUNOV ${ }^{1}$, Sulaymon VALIEV ${ }^{2}$}

Academy of the Ministry of Internal Affairs of the Republic of Uzbekistan

\begin{tabular}{l} 
ARTICLE INFO \\
\hline Article history: \\
Received September 2020 \\
Received in revised form \\
15 October 2020 \\
Accepted 15 November \\
2020 \\
Available online \\
31 December 2020 \\
\\
\hline Keywords: \\
Parliament \\
Representative bodies \\
Parliamentary control \\
Parliamentary investigation \\
Law \\
Lawmaking \\
Political parties \\
Deputies \\
Senators \\
Local government bodies.
\end{tabular}

\begin{abstract}
The article examines the formation of a new parliament in Uzbekistan, new political, legal and social responsibilities of the parliament, the gradual introduction of the institution of parliamentarism, in particular, issues of further expanding the powers of the role of parliament in the system of state power, participation of the parliament in the formation of judicial and executive power. In the article also was made proposals for the formation of a professional parliament in Uzbekistan.
\end{abstract}

2181-1415/C) 2020 in Science LLC.

This is an open access article under the Attribution 4.0 International (CC BY 4.0) license (https://creativecommons.org/licenses/by/4.0/deed.ru)

\section{Янги Ўзбекистонда миллий парламентни янада ривожлантириш истиқболлари}

\footnotetext{
Калит сўзлар:

Парламент

Вакиллик органлари

Парламент назорати

Парламент текшируви
}

\section{АННОТАЦИЯ}

Мазкур мақолада янги Ўзбекистонда янги
парламентнинг шаклланиши, бундай шароитда парламент зиммасига янги сиёсий, хуқуқий, ижтимоий вазифларнинг юкланиши, парламентаризм институтини босқичма-босқич

\footnotetext{
${ }^{1}$ DSc., Professor, Head of the Department of Crime Prevention of the Academy of the Ministry of Internal Affairs of the Republic of Uzbekistan, Tashkent, Uzbekistan

E-mail: a.s.tursunov@mail.ru

${ }^{2}$ Lecturer, Department of Crime Prevention, Academy of the Ministry of Internal Affairs of the Republic of Uzbekistan, Tashkent, Uzbekistan
} 
Қонун

Қонун ижодкорлиги

Сиёсий партиялар

Депутат

Сенатор

Махаллий давлат

органлари. кенг жорий этиб бориши, хусусан, давлат хокимияти тизимида парламентнинг ролини ошириш, суд ва ижро этувчи хокмият органларини шакллантиришда парламентнинг иштироки хамда ваколатларини янада кенгайтириш масалалари баён этилган. Шунингдек, мақолада Ўзбекистонда профессионал парламентни шакллантириш юзасидан тегишли таклифлар илгари сурилган.

\section{Перспективы дальнейшего развития национального парламента в новом Узбекистане}

Ключевые слова:
Парламент
Представительные органы
Парламентский контроль
Парламентское
расследование
Закон
Законотворчество
Политические партии
Депутаты
Сенаторы
Органы местного
самоуправления.

\section{Ключевые слова:}

Парламент

Представительные органь

Парламентский контроль

Парламентское

Законотворчество

Политические партии

Депутать

Органы местного

In each state, the parliament is a branch of government that makes its citizens feel free and prosperous or, conversely reasons for living, which takes responsibilities historically accountable to present and future generations.

The parliament of independent Uzbekistan has come a long way of development over the years. In particular, our parliament has achieved effective results based on national characteristics, experience and the practice of developed countries. The Oliy Majlis (parliament) was replaced by the Oliy Kengash, which moved from a unicameral parliament to a bicameral parliament.

Today, new reforms are undertaken to increase the role of parliament in the system of state power, to expand its powers to solve important issues of internal and foreign policy of the country, and to implement parliamentary control over the executive branch. In this regard, the head of our state Shavkat Mirziyoyev said, "Where democracy begins, it begins in parliament. We say, "Parliament is a school of democracy". Therefore, our national parliament must become a real school of democracy. In this regard, you, esteemed deputies and senators, should be an example to all. The real debate, the principled debate, must first take place here - in the parliamentary rostrum. Only then will the true image and position of every political party, every party fraction in parliament be clear"[1].

At the same time, no one denies the need to form a truly professional parliament in our country. The formation of a professional parliament depends on a number of factors. First of all, how the legal bases of the parliament is formed is important. Because the legal 
status of the parliament should allow it to function in a professional level. At the same time, it should be take in mind that the parliament itself can be professional only if it consists of professional deputies. If the deputies are not professional, then all efforts and measures to form a professional parliament will be in vain. When we talk about a professional parliament, we should also talk about the training school of the political parties that nominate candidates for it, that is, each party must prepare and form its future deputies in advance. In general, a number of factors need to be taken into account in the formation of a professional parliament in our country. Here are some of them.

Thus, in order to form a professional parliament in Uzbekistan, it is necessary to do the followings:

The first, to further expand its controlling authorities. It would be a serious mistake to say that the main task of the parliament, the legislature, is to pass laws on its own behalf. After all, passing laws is not the end of the story. In fact, the adoption of laws means half of the issue, and the other half of it is the implementation of the adopted laws. To this end, it is important that the parliament monitors and controls the implementation of laws and other normative legal acts which adopted by it.

The experience of developed countries shows that in the process of democratization, the parliament acts as a representative of the people and the legislature. At the same time, it also performs supervision functions. The controlling function is one of the most important and responsible functions of parliament. It serves to apply the principle of modern parliamentarism in socio-political life.

Parliamentary supervision ensures consistent implementation of laws, protection of human rights and freedoms, strengthening the rule of law in the state and the effectiveness of public administration[2].

In this regard, some authors think in the point of view of strengthening the activity of the implementation of laws of the Chambers of Oliy Majlis, the Oliy Majlis with the status of the legislative authority, it is also a subject of parliamentary supervision over the implementation of laws, in the Constituition must be written as "The Oliy Majlis of the Republic of Uzbekistan is the highest representative body, exercising legislative power and parliamentary control over the implementation of laws" and whether the parliament has passed laws, the function of overseeing the implementation of these laws should also be its main task[3].

Indeed, the need to increase the role of the Oliy Majlis in the system of state power, to further expand its powers to address important issues of internal and foreign policy and to protect the rights, freedoms and legitimate interests of citizens, as well as the rule of law and justice, demands to reform of the institution of parliamentary supervision.

In this regard, the powers of the parliament to monitor the implementation of laws by the executive should be further strengthened. The Law of the Republic of Uzbekistan "On Parliamentary Control" adopted on April 11, 2016 defines the objects and forms of parliamentary control[4]. However, if we pay attention to the norms of this law, we can see that parliamentary control is mainly focused on the activities of the highest subjects of the executive branch - members of the government.

But it is not defined the basis for directing parliamentary control to the activities of the middle and lower echelons of government and their leaders. However, the direct implementation of laws is carried out by the middle and lower levels of the executive branch, including state bodies and territorial branches of economic administration. 
The next logical step in the reforms aimed at increasing the impressiveness and efficiency of parliamentary control in the country should also be considered as the territorial division of the middle and lower levels of executive government, including state bodies and territorial branches of economic administration;

The second, to improve the institution of parliamentary investigation. When talking about parliamentary control, we must pay special intention to parliamentary investigation. In the legislation of our country, parliamentary investigation is defined as one of the forms of parliamentary control [5].

Parliamentary investigation is important in accurately identifying and assessing the causes, consequences, facts, etc. of certain events, incidents and processes that affect the most important interests of society and the state, which may adversely affect the basis of national security and its sustainable development.

However, the analysis shows that the legal and organizational framework for the full use of parliamentary investigation in our country is not yet sufficiently formed. A number of foreign countries have adopted separate laws on parliamentary investigation.

According to international experience, serious violations in the issuance, adoption, approval, and execution are investigated through parliamentary investigation the causes and consequences of gross or mass violations of human and civil rights and freedoms guaranteed by the Constitution, technogenic and natural emergencies, the formation and creation of state and budgetary and extra-budgetary funds. From this point of view, were held the events, processes and facts that are worth conducting a parliamentary investigation in our country (such as causes and consequences of the accident at the construction of Yunusabad metro and the collapse of the dam "Sardoba", mass frauds committed by private employment agencies, looting of funds of the Anti-Crisis Fund during the coronavirus pandemic).

Based on the above, a separate law should be adopted on issues such as the legal status of its members of the parliamentary investigation commission and the order of their work, the final conclusion of the parliamentary investigation commission, the results of the parliamentary investigation, the goals and objectives of the parliamentary investigation, its subject, duration, the initiative to initiate parliamentary investigation, the procedure for deciding to initiate parliamentary investigation, the procedure for forming the parliamentary investigation commission and others.

The third, to increase the effectiveness and validity of the results of parliamentary control.

Article 21 of the Law of the Republic of Uzbekistan "On Parliamentary Control", adopted on September 11,2016, sets out the results of parliamentary control, in this article the subjects of parliamentary control within their competence submit proposals to the President of the Republic of Uzbekistan on the results of parliamentary control, make proposals and recommendations to the relevant government agencies, economic authorities, make references, return reports, speeches, information's and other materials submitted by them for consideration with comments and suggestions to them, to send the materials of parliamentary control to the competent state bodies for consideration in accordance with its competence, appeal to the relevant state bodies, economic management bodies and officials with a request to take immediate measures to put an end to violations of the rights and legally protected interests of citizens or other violations of the legislation in the event of violations, make proposals and recommendations to the 
relevant state bodies, economic management bodies on bringing officials to justice and dismissing them from office, such as drafting a new law or initiating a review of existing legislation.

As we can see, all of the above have both recommendatory and indirect effects. The effectiveness of parliamentary control largely depends on the effectiveness of its results. Identifying problems and shortcomings is part of its solution, and overcoming them is a complete solution. In our opinion, according to the results of parliamentary control, it is expedient to be accepted by the subjects of parliamentary control to dismiss from the post the relevant officials, even members of the government, to repeal accepted normative legal acts, disciplinary prosecute officials, to warn officials not to violate the law, to submit mandatory submissions, to stop suspension of actions (inaction) of state bodies, as well as their officials, issuance of instructions that are mandatory for state bodies, as well as officials;

The fourth, to improve the legislative activity of the parliament. Unfortunately, the role of the Legislative Chamber in drafting the projects of laws is low. In particular, in 20152019, submitted law projects to the Legislative Chamber among the subjects who have the right of legislative initiative only $16.8 \%$ of the submitted law projects were submitted by the deputies of the Legislative Chamber[6]. Also parliament shouldn't stop saying it has completed its work with the passage of laws. But it should also organize the adoption of by-laws related to the implementation of these laws. For example, the full "functioning" of the enacted laws often depends on the acceptance of a relevant by-laws of legislation. On the other hand, it is not enough that the law and the by-laws are official legally compatible. There should be a conceptual harmony between them, and the rights and freedoms provided by-laws should not be stifled by the law.

The content of the legislative acts in our legislation is large, first of all, there are cases when they strengthen the departmental interests that developed it; second, they may impede the establishment of a direct enforcement mechanism for the norms of the law; thirdly, the harmony of quality of departmental documents and their compliance with other normative documents is not always at the required level[7]. Also, departmental normative-legal acts are prepared by experts in a particular field, but on the other hand, such documents may explicitly or implicitly strengthen the interests of a particular agency, court, and, as a result, undermine the public interest[8].

In some foreign countries (USA, Poland, Russia, Ukraine, France), when submitting a relevant draft of law to parliament, after adoption of this draft of law, it is necessary to introduce a mechanism to require drafts of by-laws on its implementation. For this purpose, Article 27 (documents attached to the draft law submitted to the Legislative Chamber) of the Law of the Republic of Uzbekistan "On preparation of draft laws and their submission to the Legislative Chamber of the Oliy Majlis of the Republic of Uzbekistan" adopted on October 11, 2006, when submitting a draft law to the Legislative Chamber, in connection with the adoption of the relevant law it is expedient to include in the list of bylaws documents to be submitted by the subjects who have the right of legislative initiative drafts of legal acts adopted. The Legislative Chamber will also consider draft legislation on its implementation in the adoption of the relevant law;

The fifth, to improve the system of training schools and reserve formation of political parties. In the life of the parliament play an important role its members. In other words, how is the members of parliament will be the same also the parliament. Therefore, 
it is important to nominate the most suitable candidates in the formation of the parliament. Of course, each party nominates candidates who meet certain requirements.

Unfortunately, the personnel policy of political parties today cannot be considered satisfactory. In this regard, President Shavkat Mirziyoyev addressed a video conference with representatives of the Oliy Majlis, political parties and the Ecological Movement of Uzbekistan "The formation of the personnel reserve and their professional development, the recommendation of worthy party activists to the civil service are not organized at the required level. Where do the cadres come to political parties, what is their knowledge, level, experience, reputation among the public? Who is studying this, who is evaluating it? Unfortunately, no one» he pointed out.

Therefore, it is necessary to radically improve the personnel policy of political parties. Candidates nominated by political parties must be ready to start democracy from the parliament, to turn the parliament into a school of democracy, to set an example for all deputies and senators in this regard, to have a real debate, principled debates in the parliamentary rostrum. Senators and deputies have a huge political responsibility, and their previous experience is not enough to fulfill this responsibility. Future senators and deputies must have graduated from the party's political school, boiled in the cauldron of a political party, and literally become a soldier of a political party.

The personnel policy of a political party is, of course, its own business, and the state does not interfere in this matter. However, state assistance is needed in this regard. Perhaps, the Law of the Republic of Uzbekistan "On political parties" adopted on December 26, 1996 provided an opportunity to introduce norms guaranteeing the rights of political parties in personnel policy;

The sixth, to improve the functioning of the structures that facilitate the implementation of parliamentary activities. As noted above, the parliament has been entrusted with very important tasks, that establishment of special structures is of great practical importance in the full implementation of these tasks.

Therefore, in order to increase the effectiveness of scientific, information and analytical support of parliamentary activities, radically improve the quality of legislative work of parliament, it was important the introduction of the Institute of Legislative problems and parliamentary research under the Oliy Majlis in December 29, 2017 and serves our parliament more effectively carry out its legislative function.

However, as noted above, parliament has other functions in addition to legislation. In addition, today our parliament is entrusted with a huge socio-political task - to become a real school of democracy, to be the initiator and main executor of reforms.

The institute conducts futurological research on socio-political processes, develops and summarizes large-scale analytical materials and data on reforms, the most important political, legal, economic, social and spiritual issues in a short period of time. in principle, it is required to have an institution that provides relevant information to the parliament;

The seventh, the systematization of the legislation that forms the legal basis of parliament. Over the years, a number of laws have been passed on parliamentary activities. In this regard, according to Sh.X. Zulfikarov, the laws on parliamentary activity are close in content, essence and systematization. He believes that a single "Parliamentary Code" should be developed to systematize these laws[9]. Indeed, today there is a need to systematize the legislation that forms the legal basis of parliament. 
It should be noted that in the further development of the legal framework of parliament, including the systematization, attention should be paid to the development of the legal framework of local representative bodies. Over the years, the legal framework of our national parliament, the highest representative body, has been created. However, the legal framework of territorial representative bodies does not fully meet today's requirements. Over the years, the legal framework of our national parliament, the highest representative body has been created. However, the legal framework of territorial representative bodies does not fully meet today's requirements.

In this regard, the head of our state Shavkat Mirziyoyev in his address to the Oliy Majlis said, "Local authorities and councils working on the basis of the law adopted 27 years ago, when the institution of authorities was first introduced. Given that this document does not meet the requirements of today's reforms, it needs to be radically updated"[10]. At the same time, special attention should be paid to the creation of a legal framework for the relationship between local representative bodies and parliament. After all, local representative bodies and the parliament as a single and unified representative body are not united in a common organizational and legal mechanism;

The eighth, to develop the organizational and legal framework for connecting deputies and senators with the constituency in which they are elected. In recent years, special attention has been paid in our country to such issues as visiting the regions and communicating closely with the population, studying their problems on the spot and solving them. It is necessary to ensure the active participation of deputies and senators in this process, to develop mechanisms to clearly regulate their relations with the middle and lower echelons of local government. In his address to the parliament, President Shavkat Mirziyoyev said: "I call on deputies and senators to constantly study and monitor the problems in their constituencies, the extent to which they are being addressed by the relevant ministries and khokimiyats."

Article 7 of the Law "On the status of a deputy of the Legislative Chamber and a member of the Senate of the Oliy Majlis of the Republic of Uzbekistan" adopted on December 2, 2004 (15 years ago) the rights of a deputy and a senator, which provide for the rights of a deputy and a senator mainly related to the sessions of the chamber, and the rights of a deputy and a senator in the constituency in which he is elected are not defined. Also, the norms of the law on the work of deputies with voters, political parties, the organization of the work of the deputy in the constituency, the assistance of local authorities in the organization of the deputy's work in the constituency do not fully determine the activities of deputies on the ground. In our opinion, the activity of a deputy in the constituency where he is elected should be regulated at the level of a separate legal institution. After all, the activity of a deputy should not be limited to the legislative process. He must be side by side with the people as a direct representative of the people;

The ninth, when it comes to further development of the national parliament, it is necessary to increase the role of women in the state and society, to strengthen their social status, to protect their rights and legitimate interests. In his address to the parliament, President Shavkat Mirziyoyev called on the chambers of the Oliy Majlis and the government to develop proposals for the creation of an integrated system aimed at further enhancing the role of women in society and public administration.

Thus, the issues of building a new Uzbekistan, continuing the ongoing reforms, ensuring the country's commitment to human rights and state sovereignty, achieving a 
decent life for its citizens, building a humane democratic state governed by the rule of law, strengthening civil peace and national harmony are directly related to parliamentary activities. and this in turn calls for reform of our parliament.

\section{References}

1. Report of the President Shavkat Mirziyoyev at a video conference meeting with representatives of the chambers of the Oliy Majlis, political parties and the Ecological Movement of Uzbekistan which named "Our Parliament must become a real school of democracy, the initiator and main executor of reforms" // Official website of the President of the Republic of Uzbekistan - www. president.uz.

2. Khasanov A.A. The process of democratization of the institution of parliamentary control in Uzbekistan: PhD in political sciencies. - T., 2017 - P. 11., Muxammadieva O.N. Socio-philosophical analysis of the formation and development of a bicameral parliament in Uzbekistan: PhD in philosophical sciencies. - T., 2019 - P. 5.

3. Zulfiqorov Sh.X. Improving the activities of deputies of the Legislative Chamber of the Oliy Majlis of the Republic of Uzbekistan: PhD in law sciencies. - T., 2020 P. 29.

4. Law of the Republic of Uzbekistan "On Parliamentary Control" No. LRU-403, adopted on April 11, 2016 // National Database of Legislation of the Republic of Uzbekistan - https://lex.uz/docs/2929477.

5. Law of the Republic of Uzbekistan "On Parliamentary Control" No. LRU-403, adopted on April 11, 2016 // National Database of Legislation of the Republic of Uzbekistan - https://lex.uz/docs/2929477.

6. Information on the activities of the Legislative Chamber of the Oliy Majlis of the Republic of Uzbekistan of the third convocation / Parliament.uz

7. Rahmonqulov H.R., Azizov X.T. Civil law guarantees of private property rights of a business entity: monograph. - T., 2013. - P.135.

8. Akyulov 0 . Scientific and conceptual issues of development and systematization of business legislation // Issues of improving business legislation. Collection of materials of the Republican scientific-practical conference. - T., 2015. - P. 1718.

9. Zulfiqorov Sh.X. Status of a deputy of the Legislative Chamber of the Oliy Majlis of the Republic of Uzbekistan: Doctor of Laws. dis. - T., 2020 - p 26.

10. Address of the President of the Republic of Uzbekistan Shavkat Mirziyoyev to the Oliy Majlis in December 29, 2020. 